\title{
In Praise of Tim Burton
}

\author{
By William Woof \\ Spring 1998 Issue of KINEMA
}

\section{IN PRAISE OF TIM BURTON: FINDING THE MASTERPIECE IN MARS ATTACKS}

"Science fiction is a literary province I used to visit fairly often; if I now visit it seldom, that is not because my taste has improved but because the province has changed, being now covered with new building estates, in a style I don't care for. But in the good old days I noticed that whenever critics said anything about it, they betrayed great ignorance....

A great many writers use it for satire; nearly all the most pungent criticism of the American way of life takes this form, and would at once be denounced as un-American if it ventured into any other.

C.S. Lewis"(1)

Published two years before his death in 1963, Lewis's comments on critical methods and practices were written in order to highlight the dangers of pigeonholing the entire corpus of a popular genre according to literary prejudices or the presumed practices of its readers. Lewis was acutely aware of the wide literary spectrum covered by science fiction: from mythologizing to hack writing, from eulogies of technology to outright flights of fantasy. But he had also understood those peculiarities of the American nature that combine a fast-talking entrepreneurship with a productive and industrious ingenuity to create a national character highly prone to deep, xenophobic suspicions of "alien" ideologies. We may safely assume that had his evaluation been extended to the "new building estates" of America's "golden age" of B-grade SF films of the 1950's, his analysis would have assimilated not only their tacky, exploitative nature but their glorification of technology as well. With his wonderfully understated English wit, Lewis showed a keen perception of American culture and understood why its satirical exercises so often gravitate to science fiction as its native form. No other literary genre can give more potent expression to that volatile mix of fear, intolerance, cultural naivety and technological aptitude that is so particularly American. Only in America can we imagine a speech by a head of state in which "Abraham Lincoln meets Leave it to Beaver".

Lewis's insights have been inherited in no small measure by Tim Burton, whose previous film work demonstrates his unique and often wacky grasp of that incongruity of elements that comprise science fiction. Ed Wood (1994), Burton's tribute to the hilarious ineptitude of the B-grade films that typified the 1950's milieu and its attendant subculture, combines a lucid portrayal of this world with a perceptive study of its cultural roots. Wood's incompetence in film narrative is shown as originating both in the trash writing of pulp fiction and in the typical cultural veneration of American technology. His awkward proclivity for splicing documentary footage of tanks, jets and other exemplars of American military technology into his uniquely misconstrued cinematic efforts is presented as an important condition for understanding his spectacular failures in creating effective plots and credible dialogue.

Yet Wood's bumbling efforts at merging fiction and reality provide an effective counterpoint to Burton's own achievements in elucidating the often fragile distinctions between fact and fantasy. The film's characters are frequently confused as to whether Bela Lugosi, who portrays the "undead" Dracula in the movies, is really dead. Lugosi is frequently told that he's more frightening in person than in the movies, remarks that Lugosi foolishly accepts as compliments. Burton then dramatizes these comments by portraying Lugosi's drug rehab with full chamber-of-horrors screams and effects. A different sort of twist is taken with horror film conventions used to create tension and foreboding, as Burton manipulates a potentially terrifying scene, a power failure during a carnival "spook house" ride, to stage the proposal scene of Ed and Kathy Wood. More poignant are the lines Wood pens for Lugosi in his 1955 film, Bride of the Monster, ("haunted, despised, living like an animal...") which become more of an epitaph for the real-life Lugosi than for his film character.

But Burton is also able to transpose this fusion of fiction and reality into his own narrative account of the literary roots from which Wood's bad art has devolved, effectively deploying historical references to deepen the contrast between good art and bad. One of the film's best running gags is Wood's frequent comparisons of himself with Orson Welles, which culminate in an implausible bar meeting during the filming of Wood's 
1958 film, Plan 9 from Outer Space. Despite the polar extremes between their artistic merits, both are beset by similar financial and production problems. But the deeper irony resides in the fact that Welles, unable to get his Don Quixote film project off the ground, has unwittingly met up with a real-life Quixote. Wood, of course, having no ironic distance on himself, is completely unaware of his own quixoticism. But this turns out not to be the case with Lugosi, who is portrayed by Burton as moving through Wood's movie sets in a narcotic haze, oblivious to the bad art in which he's participating. During Lugosi's rare moments of lucidity, he vaguely alludes to the rich, durable history of Dracula in literature and myth, commenting on Hollywood's ineptitude in abandoning the classic fables in favour of the bug-eyed monsters, mutant grasshoppers and brains-in-the-vat that were becoming the staples of Fifties horror films: "Who can believe such nonsense?"

Burton understands both the trend and the devolution. Like C.S. Lewis, he comprehends the unique and almost necessary fusion of satire and science fiction in the US cultural idiom, the result of America's breathless advance from one technological achievement to another. Dracula and Frankenstein were continental phenomena, dark relics of a decayed and etiolated Romanticism that worked fictionally through excavations of feudalistic horrors and fears of mad scientists and technology gone wrong. Like Don Quixote, they represented a distinctively European nostalgia, a hankering after an absurd transplantation of past virtues into the present. Post-war America, naively free of historical burdens and buoyant in its celebration of technology and equal opportunity, considered such apprehensions ridiculous and laughed at the literary pretences that engendered them. But other fears would be quickly substituted for continental ones. Anti-communist paranoia, the fear of nuclear destruction, a national xenophobia directed against foreigners or "aliens" of any description gave America a national purpose that manifested itself in the military-industrial complex, the space race and massive investments in education. Ed Wood was hardly alone in seeing opportunities in B-grade films that exploited the fears and the sense of mission that characterized the Fifties. With their clunky, techno-speak dialogues, colourless scientists, frenetic plots and cheesy special effects, the B-grade science fiction films of the Fifties gave a collective thumb of the nose to the pristine film productions of Rodgers and Hammerstein musicals, not to mention the highly literate European works of Truffaut, Resnais and Bergman. The "rah-rah", action-oriented America of the Fifties had no time to waste on the aesthetic intellectualism of what was perceived as an effete continental culture in Europe."(2)

But not all SF productions aspired to the same "lows" achieved by Ed Wood with Plan 9. Films such as The Day the Earth Stood Still (Robert Wise, 1951) and Invasion of the Body Snatchers (Don Siegel, 1956) set high standards for dramatic, imaginative, literate screenplays that would be emulated in the 1960's with A Crack in the World (Andrew Morton, 1965), Planet of the Apes (Franklin J. Schaffner, 1968) and the Outer Limits television series (Leslie Stephens, Joseph Stephano, producers, 1963-65). The classic works of science fiction literature were also discovered and film versions of many of H.G. Wells's novels were produced in the 1950's and 1960's: War of the Worlds (Byron Haskin, 1953), The Time Machine (George Pal, 1960) and The First Men in the Moon (Nathan Juran, 1964). More impressive still were crossover works like The Night of the Living Dead (George Romero, 1969), which managed to combine the low-grade horror plot of the traditional bad films with cultural and sociological insights that characterized Wells's novels.

All of this background must have been on the mind of Tim Burton when he plotted the follow- up to Ed Wood. The idea for Mars Attacks (1996) was derived from a series of trading cards produced in the early 1960's by the Topps Company and quickly withdrawn as a result of the excessive, gratuitous violence exhibited by the Martian invaders. But rather than confining himself to an exploitation of the cards' schlocky content, Burton chose to expand his film into a multi-purpose work that would provide not only a madcap parody of Fifties B-grade SF films and manifold allusions to films both good and bad, but also construct an imaginative sub-text that would tie into the classic works of SF literature -- and in particular the works of H.G. Wells. Unfortunately the film has not fared well with the critics, who have focused almost exclusively on its schlock parody.

Mars Attacks represents Burton's attempt" ${ }^{(3)}$ to get back to what C.S. Lewis called "the good old days" while keeping "the new building estates" Lewis denigrated -- and he seems entirely unafraid that critics might betray even greater ignorance than they otherwise would. Burton's chief strategy towards this objective is his adaptation of a film genre associated almost exclusively with the 1950's to a 1990's setting. And as Burton is quick to make plain, the Fifties landscape of national purpose is almost entirely unrecognizable today. In contrast to the flawless competence of the military industrial complex of the Fifties, the corporate and 
bureaucratic administrations of the Nineties are portrayed as institutions of singular ineptness. President Dale is shown as an indecisive, ineffectual leader whose idea of "taking charge of a situation" is going on national television to express his vague hopes that the collective leadership of the free world "will soon arrive at a very favourable outcome". His sleazy press secretary suggests a public "town hall meeting" as an appropriate response to the first Martian attack. General Casey, a Colin Powell look-alike and an apparent beneficiary of affirmative action policies, takes the Uncle Tom attitude that if he doesn't rock the boat, good things will happen. General Decker, on the other hand, adopts the "nuke-'em-first-ask-questions-later" approach that makes him first cousin to the "Jack Ripper" character in Stanley Kubrick's Dr. Strangelove (1964). The scientific advisor, Prof. Donald Kessler puts forward vacuous, pseudo-Orwellian assertions that there are entirely legitimate circumstances for asserting that two plus two makes five. This in turn sets up his subsequent foolish pleading with the Martian ambassador regarding the "illogical" nature of his homicidal behaviour, thus establishing a paradigm characterization of those addle-headed academics whom George Wallace once denigrated as "pointy-headed intellectuals who can't park a bicycle straight".

Burton, with his multiple settings in New York, Washington, Las Vegas, and rural Kansas, makes the point that these incompetents are not just a coterie of sycophants but typical products of a post-Reaganite America: clever, avaricious, self-promoting -- a perfect contrast to the post-war meritocracy. The wealthy are no longer the hard-driven industrialists of an Ayn Rand novel but venal, salacious opportunists. Art Land, the Las Vegas real estate developer, displays a single-track preoccupation with money which is obsessive to the point of obliviousness with respect to the dangers of the Martian invasion. Jack Nicholson plays the roles of both Land and President Dale -- the former with particular gusto -- and gets a remarkably good moment when the spacey blather of Land's telephoned sales pitch becomes comically upstaged by President Dale's televised national address confirming the discovery of extra-terrestrial intelligence. Mirroring the bad judgment and just plain ignorance of Washington politicians, Land continues with the promotional activities for his Galaxy Hotel even after the invasion is in full swing: "The Martians will need a place to stay, just like everyone else".

There is no source of core values left in America. The hard work, diligence and determination that characterized the "national purpose" America of the Fifties are nowhere to be found -- even in that traditional font of such virtues, the heartland of Kansas. The local hicks are just as addicted to the national junk culture as the denizens of Vegas. The local donut shop is as garish and artificial as anything in Las Vegas and residents tune into the same televised rubbish as the rest of the country. The gun-toting trailer family that forms the centre of interest in this Kansas setting takes a "kick-ass" approach to the Martians, the mother guaranteeing that "they'll never get the TV". The unquestioning patriotism that leads the "model son", Billy Glenn Norris, to volunteer for "Martian detail" remains, but it comes off as an empty virtue in the absence of the others. Grandma Norris pointedly refers to the others as "traitors" while the family considers it more important to honour the memory of the model son by defending the trailer against the Martians than rescuing Grandma from the seniors' home. Indeed, all of the rapid-action, "lock and load" drill routines that Billy Glenn practices at home fail him at the moment of truth when his improperly loaded magazine clip plops out of his rifle during the first Martian attack sequence.

Burton thus sets out a marked contrast between two different Americas clearly intended to exaggerate for satirical purposes the cultural illiteracy, the incompetence and absence of leadership that characterize the Nineties. This decline and fall of the American empire has already been duly noted and documented in both literature (The Image Men) and films (Network, Sidney Lumet, 1976) but Burton gives the modern state of America some novel twists in his comparisons of past with present. The First Lady, played to perfection by Glenn Close, is as obsessed with her remodelling of the White House as Art Land is with building his Vegas hotel and denigrates Eleanor Roosevelt's "fondness for chintz" as if in ignorance of her important social and cultural achievements. As she continues to throw out historical references (e.g., the "Van Buren china"), it is clear that she has as little knowledge of these references as children who play with Ninja turtles named Michelangelo and Raphael. In one of the film's best running gags, members of the Presidential family are repeatedly blocked from areas where White House tours are in progress, although it is clear that they are the ones most desperately in need of a history lesson.

Burton has taken his cue from the brilliant satire of Network, with its deranged newscaster taking aim at "a whole generation of Americans who don't know anything that didn't come out of that tube". As with 
Network, Mars Attacks achieves satiric excellence through mass caricatures of the dramatis personae -- to the extent that the straight parts stand out in stark relief, forming a much needed locus of moral characterization (e.g., the admirable dignity of William Holden's wife in Network).

As with the Bela Lugosi character in Ed Wood, Burton's heroes in Mars Attacks are those who have suffered from the affects of fame, substance abuse and/or cultural decay. They blindly and pathetically search for cultural values and achieve success almost in spite of themselves. In Las Vegas, Byron Williams, a washedup ex-boxer turned casino host (one is reminded of the humiliations suffered by Joe Louis at the end of his life) struggles to support his family and get back together with his ex-wife. Art Land's wife, Barbara, has no trouble with money but struggles with alcoholism and, with the typical zeal and naiveté of a New Age acolyte, sees in the Martians an instant solution to all the world's problems.

The young characters also seem aware of the pitfalls: Taffy, the president's daughter, reads Hermann Hesse's Siddhartha, the classic warning against the cultural decline of the West. Richie Norris, the black sheep of the Kansas family, questions his spaced-out grandmother about the wonders she's seen in her time and how marvellous it must be to witness the Martian visitation at the end of her life. Taffy and Richie, who will become the love interest at the end of the film, form mirror images of each other: Taffy is the Buddhalike Siddhartha, a well-born child of famous parents, seriously disaffected with the banality of her cultural background. (Here, we should note the comparison with Barbara Land, who packs her Buddha statue for her getaway from Vegas and assumes the Buddha-posture both in her swimming pool and on the hood of her Mercedes at the Martian landing site.) Richie, on the other hand, is the opposite of the Siddhartha: naive, unsophisticated, lowly of birth and scorned by his own family. This rejection is based on his physical awkwardness and shy, self-deprecating manner -- even his Hispanic co-worker at the donut shop pushes him around -- thus making him the opposite of his "heroic" brother, the model son, to whom his family creates a candle and portrait-laden shrine in their trailer home. Burton thus follows a standard cinematic convention in portraying Richie as the Cinderella klutz who eclipses the favoured sibling by rising to the occasion at the moment of crisis.

But Burton uses this "low art" contrast between the two brothers to underscore one of the key overall themes in the film: the dichotomy between the real and the artificial, especially with respect to genuine achievement in the values of civilization. The American obsession with superficiality and appearances is shown to have no substance; the enduring basis of cultural values must be founded on character and must be cultivated from within. This theme is introduced in the first scene of Mars Attacks and is then brilliantly incorporated into its subtext. In the film's opening scene, a White House scrum among the President's chief advisors, scientist Donald Kessler asserts that the Martians must, "by definition", be civilized and enlightened solely on account of their advanced technological achievements.

Burton thus directs attention both to his literary sources, viz. H.G. Wells, and, by subsequent association, to one of the more intense intellectual debates of the late nineteenth century. This era had not only witnessed impressive scientific and technological achievements but a precipitous decline in religious faith, as increasing prosperity created a vacuous popular culture and a growing disaffection of poets and philosophers. In a backlash against Darwinism, writers as diverse as Nietzsche, James, Tolstoy and Bergson argued that scientific advances represented a danger to mankind if not constrained by moral acuity and that such ethical know-how must increase in sophistication in tandem with scientific advances. In short, mankind's technological reach should not exceed its moral grasp. This is a particularly pervasive theme in many of Wells's science fiction tales. The Time Machine allows its hero to travel to the end of history where he witnesses the conclusion of man's technological advances: a horrifying dichotomy between a subterranean race of monsters who are entirely responsible for productive effort and a lazy, etiolated race of aesthetes who exist as little more than livestock for the subterraneans. The Island of Doctor Moreau depicts the grisly experiments of a gifted vivisectionist that are carried out in order to create a race of "beast men", humanized animals who have been given primitive, man- made powers of speech and reason. Wells clearly intended to shock the moral sense of late Victorian England with the extremes to which Moreau could take the reductions of scientific naturalism:

... the possibilities of vivisection do not stop at a mere physical metamorphosis. A pig may be educated.... Very much, indeed, of what we call moral education is such an artificial modification and perversion of 
instinct; pugnacity is trained into courageous self-sacrifice, and suppressed sexuality into religious emotion. And the great difference between man and monkey is in the larynx."(4)

Burton agrees with Wells and the fin-de-siècle thinkers that effective moral thought must be cultivated as assiduously as technological acuity and that it is a dangerous delusion to hold that scientific advances automatically entail an enlightened and civilized disposition. Burton specifically alludes to Doctor Moreau in his depiction of the Martians as amoral vivisectionists, transplanting human heads onto animal bodies and vice-versa. His comical transformation of figurative talking heads into literal ones reflects an instinctive understanding of the cultural differences between the late nineteenth and twentieth centuries. Contemporary readers of late nineteenth century fiction had enough moral fibre to be shocked by the serious presentation of Wells's fictions. The movie-goers of the twentieth century, on the other hand, are to be amused and titillated by the spectacle of bubble-headed Martians decapitating bubble-headed blondes.

Burton's intuition extends into his diptych presentation of the Martian invasion. The Fifties SF films he parodies always took their destruction sequences very seriously and audiences were expected to be shocked and offended by the spectacle of aliens destroying the landmarks of Western civilization. In Mars Attacks, the Martians blast away these monuments with all the antic irreverence of the Marx Brothers: the Presidential heads at Mount Rushmore are transformed into Martian heads; the antique stone heads at Easter Island are bowled over; the Taj Mahal is obliterated while the Martians pose for tourist photos. Burton even does a fast cut into a Godzilla film (once again obliterating distinctions between fiction and reality), showing the giant raptor out on a destruction spree without any reference to the context shift. In the next scene, the Godzilla cut is transferred to the bubble projection screens used by the Martians to monitor the output of Western films and videos. (The "Dukes of Hazard" are next up for review.) Burton thus underscores the point that major civilized landmarks and monuments have entirely lost their importance and significance in correlation to our loss of culture, historical understanding and respect for traditional institutions. Grandma Norris's hysterical laughter at the destruction of Congress registers the same comic response as the Martians twirling the Washington Monument to a crash-landing on a Boy Scout troop.

But the Martian destruction of Las Vegas is a very different matter. Because our focus of civilized values has shifted from historical and cultural landmarks to the expense and glitz of the Vegas strip, Mars Attacks makes the cheeky, scurrilously ironic assumption that our Nineties culture will be as shocked by the destruction of Vegas as the Fifties culture was by the destruction of cultural landmarks. The irony is that the Martian invasion seems largely indistinguishable from the Vegas glitz. In one of the film's most brilliant scenes, Art Land is regaling his fellow investors in the top floor board room of the Galaxy Hotel, promising bountiful returns and profits while the Martian attack is in full progress and visible through the large picture windows. Rather than run for their lives, the investors stare through windows framed by the garish murals of stars, planets, comets and eclipses, not quite sure that the spectacle isn't some stupendous publicity stunt that Land has pulled off. (This spectacle is an inversion of the televised images that proliferate throughout the film, even to the point of absurdity: e.g., the camera shots that track the launch of nuclear missiles appear to carry forward all the way into the Martian spaceship, where the comic inhalation of nuclear gasses by the Martian ambassador appears to be witnessed by President Dale.) Burton deepens the humour by using actual documentary footage of the (aptly named) Landmark Hotel, once the headquarters for Howard Hughes and his minions. The real hotel was razed on account of its continuing financial problems (thus, a humorous reflection on Land's project) and Burton incorporates both exterior and demolition shots of the Landmark into the destruction scenes of the Galaxy Hotel. (Burton's joke is that a newly constructed hotel in Vegas is architecturally indistinguishable from one ready for demolition.) The interior destruction scene includes a marvellous allusion to the beginning of the first Indiana Jones film, as a giant globe is dislodged from its mountings and rolls towards Land before crashing out the window.

Burton could have brought the Vegas destruction scenes to perfection by having the Martians trash the mock battle of Elizabethan warships staged nightly outside the Treasure Island Hotel (presumably the hotel wouldn't give him permission to do so), but his point is effectively made. The Galaxy destruction scene cuts quickly to Tom Jones singing "It's Not Unusual" at his nightclub show, his backup singers suddenly replaced by Martians and their "ack, ack" vocals. Nothing is unusual in a glitz society where taste, discretion and moderation are discounted and cultural progress is measured by the rapidity by which one outrageous spectacle supersedes another through an increase in garishness or extremity of effect. Jerry Ross, the 
Presidential press secretary, is a connoisseur of prostitutes but is incapable of detecting a preposterous Martian fake (played by Lisa Marie) as he views the deformities of her outrageous figure, body movements and bouffant hairdo as an improvement instead of a cause for suspicion.

Thus, Las Vegas represents American culture as a Babylon in an advanced stage of decay, a decline expressed in Biblical terms. Burton uses the Egyptian motifs of the Luxor Hotel to recreate the Old Testament story of the escape from Egypt into the (Nevada) desert to reach the promised land (Lake Tahoe) as Barbara Land, Tom Jones and Cindy, the barmaid, escape from the Martians by plane. Byron Williams accompanies them to the plane but then offers himself up to a Christ-like martyrdom, pictured from the air as being knocked to the ground in a supine position over a cross marking on the airstrip.

Burton then provides a counterpoint to Williams's sacrifice in the death of General Decker. Whereas Decker wraps himself in the strength of America's military might and its nuclear capability, i.e., its technological achievements, Williams throws away his weapons and armour and fights the Martians with nothing but his fists. Williams thus achieves a human dignity which eludes Decker, whose assertions of human worth are couched in second-hand quotations of Churchill's famous speeches. While Williams towers over the Martians, Decker is cut down to size by the Martian ray guns. Decker's being stepped on by the Martians finds its proper response when the resurrected Williams returns home to Washington and steps on the head of a dead Martian.

Burton thus finds a multifarious expression for his theme of the contrast of real and artificial human values. But nowhere is this theme more brilliantly expressed than in the narrative climax, the turning of the tables against the Martians which borrows its key plot device directly from H.G. Wells's classic The War of the Worlds. In the Wells story, the Martians inexplicably begin dying off at the high point of their conquest of Earth, felled by the most humble creatures in God's creation, the bacteria that invaded and ultimately destroyed their immune systems. This plot device was hardly original with Wells; it had found an earlier expression in Tolstoy's War and Peace, in which Napoleon and his massive French armies are ultimately destroyed by the humble simplicity of the Russian national spirit. But the device is enormously effective in Wells's SF story, transforming it into a moral parable of exceptional power.

In retelling this story, Burton must adapt the device to the artificiality of the Nineties culture he is depicting, and his means of doing so is ingenious. By the standards of glitz culture, the hillbilly country music of Slim Whitman is one of the most ridiculed forms of popular music, despite the fact that yodelling brings it into contact with its roots in a genuine form of folk culture. The obvious joke is that any form of intelligent life that listens to such music will have its brains turned into mush (literally), but Burton gets full mileage from the humour by getting back to the technology motif. The broadcasting power of mid-western AM radio stations was legendary and not infrequently incorporated into Fifties SF films as a means of establishing contact with aliens across interplanetary space (cf. the pilot episode for the original Outer Limits television series). In Mars Attacks, the huge towers of the Kansas radio station make Whitman's yodelling as ubiquitous as the bacteria in Wells's novel -- blasting the music out to Las Vegas and up to the Martian saucers. So, as with The War of the Worlds, it is the despised, the ridiculed and the commonplace -- in this case Richie, his granny and her Slim Whitman music -- which fulfill the heroic functions, but the double connection to the Wells classic gives Mars Attacks a powerful resonance within its subtext, a means of linking the high art of SF literature with the low art of flying saucer films. The great achievement of Mars Attacks is its progression from this fundamental linkage into the more interesting contrasts of American culture between the Fifties and the Nineties.

Mars Attacks finds numerous plot devices to express this progression. As already noted, the Fifties lionization of educational values is lampooned in characters such as President Dale and Professor Kessler. General Decker, who rails against "liberals", "intellectuals" and "peace- mongers" as "idiots", exemplifies a natural, instinctive suspiciousness of aliens which is shown to be superior to the unwarranted presumptions of intellectuals, who foolishly ascribe peaceful dispositions to the Martians. Byron Williams's two sons drive their mother to distraction by skipping school and spending their time in video arcades where they practice "zapping" the Martians with toy guns. But this frivolity is shown by Burton to have a practical purpose, as the boys are able to take charge during the Martian attack on the White House, seizing the Martian weapons and turning them on the attackers while the ineffectual White House guards are blown away. Dur- 
ing the White House tour, the boys express their wariness of the loud rumblings that presage the Martian attack. The intellectual tour guide, oblivious to the danger, misinterprets their concern as a question about a portrait of James Monroe -- whereupon she is promptly blown away by the Martians, who never miss their opportunities to stand in for portraits of American presidents. Burton repeatedly stresses his motif of academics and intellectuals who are so wrapped up in their own agendas that they are completely oblivious to outside danger.

The movie's heroes and survivors are ultimately those who are alert to their environment and do succeed in keeping their distance from the depraved and diminished American culture of the Nineties. The Williams family is portrayed as a throwback to traditional American virtues, demonstrating the same hard-working acceptance of the values of freedom shown by those American settlers who had themselves only just escaped from political oppression abroad -- and as blacks, their acceptance is appropriate for those only a generation removed from the 1964 Civil Rights Act.

Again, Mars Attacks reflects the differences between the Fifties and Nineties cultures with respect to our perception of aliens. The blacks and foreigners who were the alien outsiders of American culture in the Fifties have now been assimilated and are even capable of assuming heroic roles, acting as the benefactors of an American culture that once persecuted them. And Burton never loses an opportunity to portray such "aliens" in improbable (and what would have been seen in the Fifties as impossible) roles: black Generals and Mexican mariachis in Washington, Hispanic shop assistants in the heart of Kansas, Filipino farmers in rural Kentucky.

If we now have the capacity to stand outside of our Fifties preconceptions of what it means to be alien, perhaps Burton is suggesting that these Martians are, in fact, far less alien than they appear to be. Because they possess all the worst behavioural impulses of humans to go along with their highly advanced state of technological development, the Martians may be intended by Burton to represent a highly advanced stage of human evolution. This would certainly be in keeping with many of the themes of H.G. Wells as found in The Time Machine and The Island of Doctor Moreau that Burton has already drawn on for his film -- and he would certainly have created a masterpiece of irony if it turned out that we, in our Nineties culture, are incapable of recognizing ourselves in our future state: if we have, in effect, become aliens on our own planet. In this regard, it is interesting that the Danny DeVito character, a rude, sleazy lawyer, seems to recognize in the Martian who vaporizes him something of a spiritual fellow-traveller. Moreover, the enlarged craniums and shrunken bodies of the Martians are stock characterizations of Fifties SF not only in the depiction of aliens, but in projections of the future state of humanity. (Cf. "The Sixth Finger" episode from the original Outer Limits series.) What is particularly striking about Burton's Martians are their skeletal faces, bereft of all facial expressions save those related to cunning, hostility and malicious humour.

Finally, a few words should be said about Burton's own proclivity for self-parody. Many reviewers of Mars Attacks have offered the opinion that this is the film Ed Wood himself would have made had he possessed the financial resources. One of the objectives of this essay has been to prove this assessment inaccurate: Wood never had any ironic distance on himself and had enough trouble creating a coherent story, let alone imbuing it with a plausible sub-text. But Burton has inserted a number of Wood-like goofs in Mars Attacks that are fun to detect and not so obvious that they damage the film. For example, the van on which the female reporter stands during the Martian landing scene suddenly and inexplicably rights itself after having been flipped over in the attack. In another scene, President Dale arrives at a 4:30 P.M. news conference and says "Good Morning". The actors all seem to have great fun hamming it up in roles written to serve as exaggerated caricatures. In fact, the film has been written with more characters than can reasonably be developed within its two-hour span, with the result that the plot lines need considerable screen time to be developed. Burton then pokes fun at his own tardiness by employing a very Wood-like device: i.e., frequent cuts to outer space shots of the motionless Martian spacecraft massed around Earth's periphery as if waiting patiently for the plot to get going.

So, in conclusion, I would credit Tim Burton with considerable ingenuity for his achievement in Mars Attacks, a film that effectively bridges its Nineties setting with the world of the Fifties, the period whose values and aspirations are the basis for the SF film genre it parodies. Along the way, Burton constructs a subtext that engages the great themes of nineteenth century science fiction literature, with the consequence that Mars 
Attacks becomes transformed into a first-rate satire of modern cultural values. If we judge great films as those which achieve the lofty objectives they set for themselves, then Mars Attacks should be considered for inclusion in the pantheon in spite of the fact that it immerses itself so completely in the plot foibles and schlocky dialogue of the SF genre it parodies. The critics of the film have attacked its exaggerated characterizations almost as thoroughly as they did those of Network twenty years ago, seeing in them an intrinsic narrative flaw rather than the means to a greater satirical objective. A number of works of fantasy and science fiction, e.g., The Thief of Baghdad (Ludwig Berger, 1940), 2001: A Space Odyssey (Stanley Kubrick, 1968), The Cabinet of Dr. Caligari (Robert Wiene, 1919), The Bride of Frankenstein (James Whale, 1935), Freaks (Tod Browning, 1932), The Night of the Living Dead (George Romero, 1969), have already made it into critics' lists of most admired films" ${ }^{(5)}$ and there is no reason why Mars Attacks could not be added to the list if judged on its own merits. The film marks a serious advance on the achievements of Burton's previous work (Ed Wood, The Nightmare Before Christmas) and it is hoped that he will continue to find the means of infusing literary values into topics and themes derived from popular culture. Let's hope that his forthcoming film on Superman will once again hit the target.

\section{Notes}

1. C.S. Lewis, An Experiment in Criticism (Cambridge: Cambridge University Press, 1961), 109.

2. The best account of this American attitude is provided by H.L. Mencken, particularly his 1920 essay, "The National Letters". In his comments on this essay, Alistair Cooke notes: "... a Mencken twenty years younger, writing it in 1950, need hardly have blotted a sentence."

3. Credit should be shared with screenwriter Jonathan Gems, who also wrote the screenplay for the film adaptation of George Orwell's Nineteen Eighty-Four.

4. H.G. Wells, The Island of Dr. Moreau (London: Pan Books, Ltd., 1975), 79.

5. John Kobal, John Kobal Presents the Top 100 Movies (London: Pavilion Books Limited, 1988).

\section{Author Information}

William WOOF graduated from Wilfrid Laurier University (Hon. B.A., English, Philosophy) and the University of Waterloo (M.A., Philosophy). He is currently a Ph.D. candidate in Philosophy at York University, Toronto. 